\title{
NORDIC JOURNAL OF INFORMATION LITERACY IN HIGHER EDUCATION
}

2014, vol. 6, issue $1,1-5$

noril.uib.no

\section{Editorial}

\author{
Eystein Gullbekk ${ }^{1}$, Anne Sissel Vedvik Tonning2, Maria Carme Torras Calvo ${ }^{3}$, Therese S. \\ Skagen 4
}

${ }^{1}$ University of Oslo; ${ }^{2}$ University of Bergen; ${ }^{3}$ Bergen University College; ${ }^{4}$ Norwegian Business School

\author{
Contact: \\ E-mail: post@noril.uib.no
}

\section{EDITORIAL}

Forty years have now past since Paul Zurkowski, in his address to the US National Commission on Libraries and Information Science, introduced the term «information literacy» (Zurkowski, 1974). Information literacy (IL) has since grown as a field of academic research and over the more recent decades the term has served as an important reference for the transformation of academic libraries' user education across the globe. As an academic field of study, IL has evolved with shifting perspectives and with a cumulative growth in empirical research. In his original paper Zurkowski's concern was IL as a key prerequisite for securing broad participation in what he saw as an emergent information economy. In accordance with his political liberalism all citizens should be provided the ability to deal with information overabundance and single out «what is known or knowable on any subject» (Zurkowski, 2013, p. 23). Zurkowski's bold aim was the provision of universal IL by the year 1984. But as Whitworth (n.d.) has pointed out no direct link was made to learning or education as «there are no references to specific educational institutions, whether universities, schools or training companies, nor pedagogical approaches» (p. 1). Over the decades, however, IL has been thoroughly elaborated by several key authors in the field. Just to mention a few: We have been discussing IL as coupled with the information behaviour of different personalities (cf: Jannica Heinström's work). IL has been analysed as a process coupled with experiences within which the individual learners are seeking meaning and where the feeling of uncertainty become a framework for IL teaching and learning (cf: Carol Kulthau). And we have been dealing with IL within a relational frame (cf: Christine Bruce), which puts IL learning in a social context.

IL as conceptualised within different perspectives and paradigms has been adopted to guide IL teaching and learning across higher education (HE) institutions. The different IL standards must also be mentioned here. Thinking back about all the well informed and enthusiastically presented papers we have attended at conferences such as LILAC, Creating Knowledge, IFLA or ECIL, the IL standards have often been referred to as authoritative frameworks guiding teaching practices. As teachers within academic libraries we have been working hard to make sure that students and researchers are provided with IL and thus are enabled to «recognize when information is needed and have the ability to locate, evaluate, and use effectively the needed information» (ACRL, 2000, p. 2) or maybe to know «when and why you need information, where to find it, and how to evaluate, use and communicate it in an ethical manner» (CILIP, 2013). 
Librarians have approached IL teaching by referring to various definitions of the term and by applying different perspectives on students learning. Nevertheless, teaching initiatives has often been designed within the confines of the academic library. Green (2010) points out that librarians may have a tendency to portray students as information illiterate and thus are lacking key research skills. Librarians thus see themselves as the information experts who can fill in a void in students' pools of skills and competencies. This does not resonate with what we know about learning as a social phenomenon. Librarians as facilitators of IL learning, should build on students' existing skills, knowledge and attitudes, and partner up with other stakeholders who scaffold students' learning.

Current work seems to reestablish the link between IL and participation by critical thinking and action. For instance one insight from the US-based «Project Information Literacy» (PIL) is that the ability to evaluate information and to recognize context is becoming a key skill (Head, 2013). Another sign could be the way IL standards are being radically revised or even redesigned. In the drafted revised version of the ACRLs Framework for Information Literacy for Higher Education, we find an interesting reference to metaliteracy as they stress the value of critical self-reflection as learners engage with information in a broader information eco-system (ACRL, 2014, p.2). Stated here is the idea that the framework should be received not as a prescription for teaching within local institutions, but as a starting point for designing outcomes based on local purposes and practices. Similarly we find in «A new curriculum for Information Literacy» (Secker \& Coonan, 2011) the idea that an IL framework should not be a library-owned product. Rather, when implementing the framework, academic libraries need to partner with other stakeholders in student learning, such as lecturers and supervisors. Another key partnership that library and information experts and practitioners needs to foster is with media literacy experts and practitioners. They are equally engaged as us in empowering citizens through key competencies. In a world where rapidly evolving information technology is transforming access to information, it is important to understand the connections between information and media literacy from a multi stakeholder perspective, as UNESCO (n.d.) has been encouraging through several initiatives ( Global Alliance for Partnerships on Media and Information Literacy, GAPMIL) and publications ( MIL Curriculum for teachers, MIL Policy and Strategy Guidelines). Promoting (media and) information literacy requires joint research and work across geographical, sectorial and professional boundaries.

We believe that research based knowledge has been one prerequisite for an enthusiastic and sound development of relevant and influential teaching practices that have the potential of making a difference for students learning efforts across HE institutions. And surely, we believe that partnership within practice, research based revisions of frameworks and the inclusion of emerging platforms and arenas for students work and learning will add value to how we approach for student learning.

The four articles in this issue of NORIL all provoke our reflection with respect of increased complexities in the information landscape, the development of student and researcher IL within the landscape, and with respect of emerging technologies.

Barbara A. Sen and Pamela McKinney's article deals with IL assessment. In their article, they discuss the use of a particular institutional developed model, the SEA-change model, as a means to assess students' IL development. The overall aim of their article is to evaluate the value of reflective writing as part of students' IL development. Sen and McKinney demonstrate how reflective practices are increasingly important for learning, also as facilitated academic libraries.

Sharon Favaro and Christopher Hoadley's concern is IL as embedded in the workflow of doctoral students in an information rich landscape. They pay attention to increasing complexities in digital tools and platforms. The authors envision a future role for libraries as experts in integrated information management. In order to develop such a role however, libraries need to gain knowledge about emergent practices in research and learning. How do 
available digital tools and library resources support students' and researchers' workflow? The article addresses the heterogeneity of practices and the challenges faced by students, researchers, advisors and librarians alike.

Andrew Walsh invites us to pay attention to gamification as a technique libraries can use in order to enhance students' use of library resources throughout their studies. Walsh shares with us findings from their implementation of «Lemontree», a gamification project, indicating that gamification could be part of a suite of tools to strengthen social contexts for learning.

Kaisa Puttonen shares with us a multidisciplinary approach to IL teaching. IL teaching and learning should not be a library owned concern. Puttonen describes a case in which an IL teaching initiative is developed in collaboration between library staff and ICT lecturers. She discusses how students' development of basic computer skills and IL skills may be met in a virtual face-to-face learning environment.

\section{NORIL and the future}

The scope of NORIL's interests is to contribute to a better understanding of the relationship between research based knowledge and learning processes in HE sector, and teaching practices within the field of IL.

After five years with NORIL our focus has been to publish original research articles which are peer reviewed, and special issue of conference proceedings. Starting with this issue, we have expanded categories of articles to include best practice. In the best practice section we would like to receive submissions on topics that concern you in your practice as an information specialist in HE. For example; how do you experience collaboration with the academic community, such as planning, implementation and evaluation and/or assessment of IL learning or guidance? Or have you tried out some tools that seem to be working in class and want to share your experience? We would like to invite you to write it up and send us a short paper for publication!

From the next issue on, we also will include reports as another text category. Foremost we aim at collecting summary of reports on IL and HE related to the Nordic countries either in content or authorship. We would therefore encourage you to contact NORIL if you know about projects coming up, or would like to publish recent existing reports in NORIL.

The editors have long discussed how we can expand the editorial team so that NORIL can continue as an OA journal, and eventually also have two regular annual numbers, besides conference proceedings issues. NORIL has for several years been working with the international conference Creating Knowledge, and the Norwegian national conference for academic librarians in $\mathrm{HE}$, and has published their conference proceedings. We have now established a closer cooperation with the steering committee in NordINFOLIT, who owns of the Creating Knowledge conference, and thus extended the editorial team with the current board members from the Nordic countries. In this way, we hope to strengthen the connection to the other Nordic countries' national conferences, and hopefully inspire to different texts in all categories published in NORIL. From the next issue therefore, we welcome Astrid M. Magnusdottir, Iceland, Bolethe Olsen, Greenland, Erhard Jacobsen, Faroe Islands, Jesper Mørch, Denmark, Paivi Helminen, Finland and Riitta Kairakari, Sweden as editors of NORIL. Anne Sissel Vedvik Tonning is the Norwegian member in NordINFOLIT's steering committee and also one of the present editors in NORIL.

Of course, we welcome authors from all countries to submit their paper to NORIL!

NORIL still aims at: 
- Encouraging research based development of information literacy teaching within the educational programmes of universities and higher education colleges

- Establishing a forum for the investigation and discussion of connections between information literacy and general learning processes within subject-specific contexts

- Encouraging to increased collaboration between library and faculty

- Contributing to the development of a body of knowledge on the topic of learning and teaching in the library context

- Disseminating developments within the area of library pedagogy

- Inspiring debate in the field

The Editors are grateful to the Editorial Board and their network for their thorough referee-work. We hope you will enjoy this issue of NORIL. 


\section{References}

Association of College and Research Libraries / American Library Association. (2014). Information Literacy Competency Standards for Higher Education (Draft). Retrieved from http://acrl.ala.org/ilstandards/wp-content/uploads/2014/02/Framework-for-IL-forHE-Draft-2.pdf

Association of College and Research Libraries / American Library Association. (2000). Information Literacy Competency Standards for Higher Education. Retrieved from http://www.ala.org/acrl/sites/ala.org.acrl/files/content/standards/standards.pdf

Chartered Institute of Library and Information Professionals (CILIP). (2013). Information literacy - Definition. Retrieved from http://www.cilip.org.uk/cilip/advocacy-campaignsawards/advocacy-campaigns/information-literacy/information-literacy

Green, R. (2010). Information Illiteracy: Examining our Assumptions. Journal of Academic Librarianship, 36(4), 313-319.

Head, A. J. (2013). Learning the Ropes: How Freshmen Conduct Course Research Once They Enter College, Project Information Literacy Research Report: The Passage Studies: Information School, University of Washington.

Secker, J., \& Coonan, E. (2011). A new curriculum for information literacy. Curriculum and Supporting Documents. Cambridge University Library. Retrieved from http://ccfil.pbworks.com/f/ANCIL_final.pdf

Zurkowski, P. G. (1974): The Information Service Environment: Relationships and Priorities, Report presented to the National Commission on Libraries and Information Science, Washington DC.

UNESCO (n.d. ). Framework and Plan of Action for the Global Alliance for Partnership on Media and Information Literacy (GAPMIL). Media and Information Literacy (MIL) as a Means to Open and Inclusive Development Retrieved from http://www.unesco.org/new/fileadmin/MULTIMEDIA/HQ/CI/CI/pdf/Events/gapmil_fr amework_and_plan_of_action.pdf

Whitworth, A. (n.d.). Introduction. Retrieved from http://personalpages.manchester.ac.uk/staff/drew.whitworth/burchinal.html 